CAHIER DE RECHERCHE \#1906E

WORKING PAPER \#1906E

Département de science économique

Department of Economics

Faculté des sciences sociales

Université d’Ottawa

Faculty of Social Sciences

University of Ottawa

\title{
Terrorism, Immigration and Asylum Approval $^{*}$
}

\author{
Abel Brodeur ${ }^{\dagger}$ and Taylor Wright
}

October 2019

\footnotetext{
${ }^{*}$ We gratefully acknowledge comments from Jason Garred, Anthony Heyes, Paul Makdissi, Louis-Philippe Morin, Soodeh Saberian, and Matt Webb. Any remaining errors are our own.

${ }^{\dagger}$ Department of Economics, University of Ottawa, 120 University Private, Ottawa, Ontario, Canada, K1N 6N5; email: abrodeur@uottawa.ca.
} 


\begin{abstract}
Using the universe of individual asylum cases in the United States from 2000-2004 and a difference-indifferences research design, we test whether Sept. 11, 2001 decreased the likelihood that applicants from Muslim-majority countries were granted asylum. Our estimates suggest that the attacks resulted in a 3.2 percentage point decrease in the likelihood that applicants from Muslim-majority countries are granted asylum. The estimated effect is larger for applicants who share a country of origin with the Sept. 11, 2001 attackers. These effects do not differ across judge political affiliation. Our findings provide evidence that emotions affect the decisions of judges.
\end{abstract}

Key words: Courts, Crime, Immigration, Judicial Decision, Sentencing and Terrorism.

JEL Classification: D74, K4, K37 and P48.

\title{
Résumé
}

Cette étude se base sur l'univers des demandeurs d'asile aux États-Unis sur la période 20002004 et sur la méthode de différences-en-différences pour tester si le 11 septembre 2001 a diminué la probabilité que les demandeurs originaires de pays ayant une majorité de population musulmane obtiennent l'asile. Nos estimés suggèrent que le 11 septembre 2001 a diminué de 4 points de pourcentage la probabilité que les demandeurs originaires de pays ayant une majorité de population musulmane obtiennent l'asile. L'effet estimé est plus grand pour les demandeurs provenant de l'un des pays des dix-neuf terroristes. De plus, l'effet estimé ne diffère pas selon l'affiliation politique des juges. Nos résultats suggèrent que les émotions peuvent affecter les décisions des juges.

Mots clés : Tribunaux, criminalité, immigration, décision judiciaire, détermination de la peine et le terrorisme.

Classification JEL :D74, K4, K37 and P48. 


\section{Introduction}

How do emotions such as anger, fear, or sadness influence peoples' decision making? An extensive body of research assesses the part extraneous information and emotions play in how people make evaluations and judgments. However, relatively little analysis has investigated the effect of catastrophic events such as Sept. 11, 2001 and their resulting emotions on decision making.

One of the founding principles of the United States is equal and fair treatment under the law. The influence of emotions and extraneous information on judges' decision making is a deviation from this principle and a miscarriage of justice. Moving from the macro to the micro, the individuals applying for asylum (asylees) are doing so in order to flee persecution from their country of origin on the grounds of race, religion, nationality, belonging to a particular social group, or political opinion. Asylees who are deported unjustly face poverty, violence, torture, and/or death (see for example Andrews et al. (2019), Brodzinsky (2015), Bulman (2018), or Stillman (2018)). Clearly, these are high stakes decisions that require the evaluation and removal of underlying judicial prejudice. We believe that documenting the magnitude of the effect of terrorist attacks on asylum approval is therefore meaningful and important.

Islamic terrorism may affect judges' decision making through several different mechanisms. Emotions have been shown to not only color the immediate and related judgments and evaluations, but also those that are unrelated and occur much later (Lerner et al. (2015)). According to this mechanism, the Sept. 11, 2001 attacks represent a negative event and as a consequence we might expect to see lower asylum grant rates. If cases of asylees from Muslim-majority countries create emotional cues related to the attacks, we might expect the decline in asylum grant rates to be even larger for asylees from those countries. ${ }^{1}$

Our empirical strategy investigates how Sept. 11, 2001 (and the March 11, 2004 attacks that occurred in Madrid, Spain) changed asylum grant rates for asylees from Muslim-majority countries in American immigration courts. Using the universe of asylum cases in the United States from January 2000-September 2004, we employ a difference-in-difference research design with applicant and temperature controls alongside judge, city, month, and city-month fixed effects. We address potential selection

\footnotetext{
${ }^{1}$ Other possible channels include judges updating their perceptions of the frequency of Islamic terrorism or terror-related changes in local economic conditions. See Section 3 for more details.
} 
issues by exploiting random judge assignment; the presence of lengthy, case backlogs; and creating windows around the attack date.

Our estimates suggest that asylees from Muslim-majority countries are about 3.2 percentage points less likely to receive asylum than those not from Muslim-majority countries. We also provide evidence that asylees from attack associated countries are between 6-10 percentage points less likely to receive asylum than those not from countries associated with Sept. 11, 2001. We find asylees from Muslim-majority countries are also about 2.2 percentage points less likely to receive asylum after the Madrid attacks. Our results also suggest that Democrat appointed judges do not respond to the attacks in a different way than do Republican appointed judges.

This paper is related to the literature on emotional shocks and decision making, extraneous information and judicial bias, and the consequences of terrorism. Several studies examine the effects of negative emotional shocks on various outcomes. Beland and Brent (2018) find that emotional shocks from extreme traffic in Los Angeles increases domestic violence while Card and Dahl (2011)) find that unexpected local football losses increase domestic violence in the United States. Eren and Mocan (2018) find that unexpected college football losses by a judge's alma mater result in harsher juvenile sentencing in Louisiana.

Our paper also relates a growing literature examining the impact of extraneous information on the decisions of judges (e.g. Danziger et al. (2011)). Heyes and Saberian (2019) examine the impact of pollution and temperature on immigration judge asylum decisions, finding that extreme temperature results in lower likelihood of asylum. Philippe and Ouss (2018) explore the impact of crime on jury decision making in France and conclude that new coverage of unrelated crimes increases sentence length. Shayo and Zussman (2011) find that Arab and Jewish small claims judges are biased in favor of their own groups, and that this bias is strongly related to the intensity of nearby terrorism in the previous year. Our work is also very closely related to McConnell and Rasul (2019), who examine the spillover effects of the Sept. 11, 2001 attacks on differential sentencing of hispanic and black defendants in the U.S. finding that hispanic defendants experienced worse outcomes as a consequence. ${ }^{2}$

\footnotetext{
${ }^{2}$ Also of note is work examining racial bias in the judicial system: Alesina and La Ferrara (2014) find evidence of bias in U.S. capital sentencing against minority defendants; Anwar et al. (2012) find bias in Florida conviction rates of black defendants when there were no black jury members; and Cohen and Yang (2019) find that U.S. Republican-appointed judges deliver harsher sentences to black defendants and the difference between white and black defendants grows with judge discretion.
} 
Our work contributes to these existing behavioral literatures in two key ways: first, we examine the effect of a single catastrophic Islamic terrorist attack (and its resulting emotional shock) at a time in the U.S. when there had been essentially no Islamic terror attacks committed $;^{3}$ second, we are examining the decisions of immigration judges rather than those of small claims judges or juries where the degree of judge discretion and stakes of the decisions are quite different.

Previous empirical work has focused on examining the effect of terrorism on many outcomes which, although closely related, differ from ours. We contribute here by documenting the effects of terrorism on asylum approval for those from Muslim-majority countries, and judge decisions. Dreher et al. (2017) estimate the impact of changes in immigrant stocks on the probability of terror attacks in the host country, finding no evidence that terrorism is imported from Muslim countries or other countries with significant terrorism. ${ }^{4}$ Cornelissen and Jirjahn (2012), Dávila and Mora (2005), Kaushal et al. (2007) document the impacts of Sept. 11, 2001 on labor market outcomes of Arabs and Muslims. ${ }^{5}$ Our work also ties in with studies examining the effect of terrorism on changes in ethnic attitudes (Ratcliffe and von Hinke Kessler Scholder (2015)), self-identification among Arab and Islamic Americans (Mason and Matella (2014)) and integration and assimilation (Bisin et al. (2008), Elsayed and De Grip (2018), Gould and Klor (2016)).

Last, our work complements studies documenting the consequences of transnational terrorism on fear, uncertainty, and behavioral responses to those emotions. We mostly relate to the contributions of Becker and Rubinstein (2011) who argue that terrorism may lead to intense fear of future dangers and Brodeur (2018) who provides empirical evidence that terror attacks in the U.S. decrease consumer confidence.

The paper is structured as follows. Section 2 provides background for the the entry of asylum seekers into the U.S. and the role judges play in the asylum process. In Section 3, we provide a conceptual framework and review the literature on behavioral biases. Section 4 describes the data used and provides summary statistics. Section 5 outlines our empirical strategy and model specifications. Section 6 presents our results. The last section

\footnotetext{
${ }^{3}$ Therefore the social division generated by these attacks is significantly less ingrained than in an ongoing conflict context.

${ }^{4}$ Avdan (2014) finds that terrorism in Europe results in migration restriction for countries who experience attacks, but does not result in the erosion of the humanitarian principles backstopping asylum recognition.

${ }^{5}$ See Abadie and Gardeazabal (2003), Blomberg et al. (2004), and Crain and Crain (2006) for the macroeconomic consequences of terrorism.
} 
concludes.

\section{Asylum and Immigration Judges}

In this section, we first briefly describe how immigration judges are hired, by whom, and what their qualifications and backgrounds look like. We then provide an overview of the asylum process in the United States.

\subsection{Immigration Judges and the Executive Office for Immigra- tion Review}

Asylum adjudication is carried out by the Executive Office for Immigration Review (EOIR) which was created in 1983 after a restructuring of the Department of Justice (DOJ). Its creation separated asylum adjudication from the enforcement of immigration laws (formerly the Immigration and Naturalization Service (INS) which is now part of the Department of Homeland Security (DHS)). The EOIR is tasked with carrying out immigration court hearings, administrative hearings, and appellate reviews and does so with delegated authority of the Attorney General. The Director of the EOIR reports directly to the Deputy Attorney General (Department of Justice (2018a)).

Formally, the Attorney General makes immigration judge appointments however the hiring process is conducted by the EOIR. The requirements for becoming an immigration judge include being a U.S. citizen or national in possession of a law degree with at least 7 years of post bar legal experience who is authorized to practice law as an attorney in the U.S. Applicants are also required to submit a writing sample to demonstrate their ability to author legal documents (Department of Justice (2018b)).

We manually collected judge characteristics for all the judges in our dataset (see Section 4 for more details) and use those with full enumeration as controls. Unfortunately, the data is incomplete as we are missing complete biographical information for about 10 percent of our judges. Of the judges for which we have complete information, about 50 percent had previously worked for the INS in some capacity, often as trial attorneys. Around 45 percent of judges had previously worked in legal aid, nearly the same proportion as having worked for a firm or in private practice. These background characteristics are not mutually exclusive and it is common for judges to, for example, have worked for the INS and also have worked for a firm or legal aid organization. 
Immigration courts are often not staffed with law clerks to provide additional research assistance or bailiffs (unless the hearing are taking place at a detention center) and judges are required to manage their own recording of proceedings (National Association of Immigration Judges (2011)). These resource issues are compounded by a heavy workload - making hundreds of decisions each year and hearing several times that many - and hundreds of thousands of backlogged cases. ${ }^{6}$ Perhaps as a result of these conditions, the EOIR and DOJ are not able to fill vacancies in a timely manner and there have been concerns with the temperament, quality, and performance of judges from Federal courts and the Attorney General (Cable News Network (CNN) (2006); Liptak (2005); National Association of Immigration Judges (2011)).

\subsection{The Asylum Process}

Asylees apply for refugee status from within the United States, either in response to being deported or proactively, to escape persecution in their own country. Their cases are heard by randomly assigned immigration judges who are institutionally independent of immigration enforcement, typically in the court closest to their physical location at the time of the application (Miller et al. (2015); Refugee, Asylum, and International Operations Directorate (2016)). Hearings are adversarial and asylees must provide their own legal representation (Ramji-Nogales et al. (2007)). In our empirical analysis, we control for whether applications are affirmative or defensive, whether or not the asylee has legal representation, and whether or not the asylee was detained. We also use judge fixed effects (or in the case of our DDD analysis control for judge gender, experience, and the party in control of the White House when they were appointed).

\section{Conceptual Framework}

Immigration judges are required to determine whether or not the fear of persecution is "well-founded". The fundamental directive immigration judges are given is to evaluate the eligibility and assess the likelihood of an asylee's persecution upon return to their country of origin. ${ }^{7}$ Nonetheless, immigration judges have significant discretion in adjudicating cases - the definitions of terms like "persecution" used in establishing eligibility for asylum are

\footnotetext{
${ }^{6}$ There are currently over 800,000 cases that are pending but undecided. In our sample, there were approximately 150,000-200,00 pending cases (TRAC (2018)).

${ }^{7}$ The lack of research resources and time constraints they face may make them reliant on existing reports produced by the State Department (Miller et al. (2015)).
} 
vague or left up to individual judges as is the estimation of probabilities of persecution.

There are thus several channels through which Islamic terror attacks could influence immigration judges' decision making. We first focus our attention on unconscious or behavioral mechanisms. We then discuss other mechanisms through which Islamic terrorism could affect judges' decisions.

\subsection{Behavioral Biases}

The institutional setting and context in which immigration judges operate may make them more likely to bring their policy preferences and personal biases to bear on the cases they examine, using them to filter case facts, regardless of legal merit.

There is substantial evidence from economics, psychology, and neuroscience that emotions influence decision making (see Lerner et al. (2015) for a an overview). This is relevant in our context since negative emotions may lead to pessimistic evaluations (Johnson and Tversky (1983)). ${ }^{8}$ This is complemented by findings that emotions persist, continuing to influence decisions that are unrelated to the emotion (e.g., Han et al. (2007)) Again, this is important for our context as if emotions persist, then those pessimistic evaluations can occur in a context entirely divorced from that which generated the emotion. There is a burgeoning empirical literature documenting this concept. For example, Lerner et al. (2003) conduct a field experiment in the aftermath of Sept. 11, 2001 where participants are treated with news articles inducing fear or anger. They find that those affected by fear viewed the world with greater risk and those with anger with less risk. Important for our research, those affected by anger supported more harsh treatment of suspected terrorists than those affected by fear.

Two other relevant studies are Eren and Mocan (2018) and Philippe and Ouss (2018). Philippe and Ouss (2018) examine the effect of news coverage of unrelated crime on juror sentences and find an increase in sentence duration. They also explore whether or not this is something specifically related to crime or whether or not crime is another form of bad news, finding that other forms of bad news that may affect mood do not influence juror decisions. Eren and Mocan (2018) explore the effect of unexpected football team losses on juvenile court judges in Louisiana and find that

\footnotetext{
${ }^{8}$ Danziger et al. (2011) find that the order in which parole judges review cases and the timing of food breaks influences judge decision making, though whether the mechanism is the break, food, or possible change in mood is unclear.
} 
emotional shocks result in harsher sentencing of black juveniles. ${ }^{9}$

To the extent that judge characteristics determine which emotion was felt by the attack itself, the attacks may influence judge behavior in different ways. These potentially heterogenous emotional responses combined with the importance of immigration judge policy preferences are key reasons for our collection and use of experience and appointing political party as controls and factors that may generate heterogenous treatment effects.

\subsection{Other Mechanisms}

Terrorism and the associated media coverage could shift the perceptions of the frequency of Islamic terrorism. This is a cognitive effect known as the "availability heuristic", which is a mental shortcut in which a person's perceived frequency of an event is influenced by how easily they can call to mind an instance of that event (Tversky and Kahneman (1973)). While the change in perceived frequency is an unconscious decision, the decision to rely on "gut feelings" and avoid challenging or updating those perceptions is conscious. This effect could also interact with the country of origin, as Islamic terrorism could alter the perceived frequency of individuals from Muslim countries being terrorists. These two consequences of Islamic terrorism offer an alternative, conscious mechanism that explains changes in judges' decision making, specifically for asylees from Muslim-majority countries.

In Section 1 we referenced the body of existing research documenting the consequences of terrorism on assimilation, integration, and labor markets. If immigration judges are influenced by local conditions then this existing research suggests a mechanism other than emotion through which judges' decision making could be altered. Miller et al. (2015) suggest that judges can be influenced by local conditions, drawing on other research indicating that judges' decisions in other contexts correlate strongly with local attitudes; that opposition to immigration is tied to local labor market conditions; and that immigrants are a fiscal burden on their local governments.

\footnotetext{
${ }^{9}$ Card and Dahl (2011) find that unexpected football team losses cause an increase in domestic violence mediated by a change in mood. They describe a 'gain-loss' utility framework where sport team losses result in fluctuations around a rational reference point.
} 


\section{Data}

Our data on asylum decisions is administrative, case-level data containing the universe of asylum cases in the United States occurring between January 2000 and September 2004. Our data comes from asylumlaw.org, a now defunct website that was a collaborative effort by international agencies to assist asylum seekers in many countries, including the United States. The website contained information and resources including those related to legal and human rights; and immigration and asylum experts. ${ }^{10}$ In total, we have 269,270 asylum decisions made by 262 immigration judges across courts based in 43 cities.

The dataset contains information about the date and location of hearing, the judge responsible for the case, whether or not an applicant had legal representation, the nationality of the applicant, whether or not the application was in response to deportation proceedings. We merge this data with information about the share of the population that is Muslim in the applicant's country of origin. ${ }^{11}$ Additionally, we are able to determine whether or not an applicant was detained in an institution during their hearing. The dataset contains information not only on cases where some form of asylum is denied or approved, but also cases that are withdrawn or dismissed. These applicants are less likely to have legal representation $(69 \%)$ and less likely to be filing defensively (21\%). In our analysis, we include dismissed and withdrawn cases but our results are robust to their exclusion (see Section 6).

We collected biographical information about each judge in the sample. Our primary data source for collecting judges' characteristics is the judge reports from the Transactional Records Access Clearinghouse (TRAC) which is a data collection, research, and data warehouse based out of Syracuse University. Their website contains reports for judges each year in which the judge decides at least 100 cases. The judge information was collected from "a variety of official sources including press releases, testimony, other biographical information released by the Department of Justice, and responses received to specific TRAC inquiries" (TRAC (2008)). Unfortunately, the 100 decision per year threshold in the TRAC data leaves 30 of the 262 judges missing. We used internet searches, relying on DOJ and other gov-

\footnotetext{
${ }^{10}$ Data retrieved from Heyes and Saberian (2019).

${ }^{11}$ Data about the share of the population that is Muslim in each country is drawn from 2010 estimates by the Pew Research Center's Forum on Religion and Public Life and we define a country as Muslim-majority if greater than $50 \%$ of their population is Muslim. Note that our definition of Muslim-majority countries would not change if we were using 1990 instead of the 2010 estimates.
} 
ernment documents or newspaper articles, to compile information about these judges. We were able to obtain gender for all judges and year of appointment for all but four. Unfortunately, information on the backgrounds of these judges was not as readily available and as such, we do not use this information in our analysis.

We collected information about judge gender, year of appointment, and backgrounds prior to appointment. We used the year of appointment to construct variables indicating the amount of experience a judge has at the time of Sept. 11, 2001. Last, we construct a dummy variable for which political party held the Presidency at the time of the judge's appointment. This variable serves as a measure of a particular judge's ideology as judges are hired by the executive branch of the U.S. government.

There is a large degree of variation in asylum approval rates between courts. For instance, in 2001, the court in San Francisco, California approved 65 percent of cases while the court in Philadelphia, Pennsylvania approved 29 percent of cases. There is also a large degree of variation in approval rates within courts: approval rates in 2001 ranged from 6 percent to 93 percent in New York, New York for judges who adjudicated at least 200 cases. Importantly for our analysis, cases are randomly assigned to immigration judges within a court. In the absence of random case assignment our identification strategy would be threatened by sorting of Muslim cases to judges less (or more) likely to grant asylum.

Table 1 provides summary statistics across our sample on asylum outcomes and case characteristics for the U.S. as a whole. Each of the variables contained in Table 1 are binary variables and thus the means presented represent the share of cases for which the statement is true. The mean grant rates for asylees is $18.3 \%$ with a standard deviation of 38.7. For asylees from Muslim-majority countries the mean grant rate is $28.3 \%$ with a standard deviation of 45.1. Over 80 percent of asylees have a legal representative and 7.7 percent were detained. Just under 30 percent of applications are defensive (in response to removal proceedings) and just over 70 percent are affirmative (no removal proceedings being pursued). ${ }^{12}$ About 15 percent of asylees have a Muslim-majority country of origin and 1.5 percent share a country of origin with a perpetrator of the Sept. 11, 2001 attacks.

Around 70 percent of applications were heard by judges appointed by a Democrat. Applications were heard by female judges around 36 percent

\footnotetext{
${ }^{12}$ Removal proceedings may occur as a result of criminal convictions, determination of illegal entry into the United States, or possession of insufficient documentation at border crossings.
} 
of the time. Just under 35 percent of applications were heard by a judge who had between 0 and 5 years of experience. Judges between 6 and 10 years of experience heard 44 percent of applications while those with over 10 years of experience handled the remaining 21 percent or so.

\section{Identification Strategy}

The objective is to estimate the impact of terrorism on judges' decisions when granting asylum. We rely on two empirical models.

Difference-in-Differences - In our main empirical analysis, we implement a difference-in-differences (DD) research design by comparing the asylum grant rates of asylees from Muslim-majority countries and asylees not from Muslim-majority countries, before and after Sept. 11, 2001. In our main specification, we estimate

$$
\begin{aligned}
& y_{i t m j c}=\alpha+\beta \text { Muslim }_{i}+\delta{\text { Post } 911_{t}+\gamma \text { Muslim }_{i} \times \text { Post }_{1} 11_{t}+} \\
& X_{i}^{\prime} \psi+\text { temperature } e_{c t}+\lambda_{j}+\tau_{c}+\omega_{m}+\rho_{c m}+\varepsilon_{i t j c}
\end{aligned}
$$

where $y_{i t j c}$ is a binary variable that equals one if a judge $j$ grants asylum

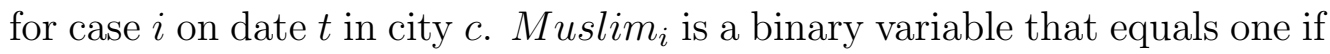
the asylee is from a Muslim-majority country and zero otherwise. Post911 is a dummy for whether case $i$ was judged after the attacks. Our coefficient of interest in this model is $\gamma$. It shows the effect of DD interaction term, Muslim $_{i} \times$ Post911 $_{t} . \quad X_{i}^{\prime}$ is a vector of case specific variables including whether or not the individual is detained at the time of the hearing, has legal representation, and is filling affirmatively or defensively. temperature ct $_{\text {t }}$ measures the mean temperature from $6 \mathrm{am}$ to $4 \mathrm{pm}$ in city $c$ on date $t$ and is included following Heyes and Saberian (2019). $\lambda_{j}, \tau_{c}, \omega_{m}$, and $\rho_{c m}$ are judge, city, month, and city-month fixed effects, respectively.

We also estimate Equation (1) replacing Muslim $_{i}$ with a binary variable Associated $_{i}$ that equals one if the asylee is from a country associated with the Sept. 11, 2001 attacks and zero otherwise. Associated countries are defined as the countries of origin of the 19 attackers: one from Egypt, one from Lebanon, two from United Arab Emirates, and 15 from Saudi Arabia. This alternative specification test whether the effect of Sept. 11, 2001 is larger/smaller for this subgroup of asylees. We hypothesize that the

effect is larger since the behavioral biases discussed in Section 3 could be 
magnified for asylees from these countries. Again, the coefficient of interest is the DD interaction term, this time between Associated $i$ and Post911. We exclude Muslim-majority countries other than those associated with the attack, making the comparison between asylees from attack-associated countries and those from non-Muslim-majority countries.

Additionally, we estimate Equation (1) replacing Post911 $t$ with a binary variable Post $311_{t}$ that equals 1 if the hearings are heard after the March 11, 2004 terror attacks conducted in Madrid, Spain. The coefficient of interest



We consider the treatment as being applied at the country level with Muslim-majority countries as being treated and non-Muslim-majority countries as untreated. We cluster our standard errors at the country of origin level because it seems likely that the unobservables of asylees will be correlated within countries (e.g. spoken languages, or religion). We have 204 clusters in total.

Our identification assumption is that in the absence of the Sept. 11, 2001 attacks, the change in the grant rates of Muslim-majority countries and other countries would not be different, conditional on controls. We visually demonstrate that this parallel trends assumption holds for the pretreatment period. Figure 1 plots the monthly average asylum grant rate over our entire sample (January 2000 to September 2004) for asylees from Muslim-majority countries and asylees not from Muslim-majority countries. The vertical line represents the Sept. 11, 2001 attacks. Figure 2 plots the analog for asylees from countries associated with the attacks. In Figure 1 , we can see that prior to the attacks, the grant rates for both groups were trending upwards. Asylees from Muslim-majority countries were much more likely to be granted asylum than those from non-Muslim countries and it appears as though there is a slight convergence in grant rates in the postattack period. In the year or so prior to the attacks, the monthly average for asylees from Muslim-majority countries was nearly as likely to be above $30 \%$ as below it and was above $30 \% 8$ times. In the just over 2 years after the attacks, however, only six months broke $30 \%$ and several months fell at or below below 25\%. For those from non-Muslim countries it appears there is a leveling off of the growth in grant rates after the attacks with the average asylum grant rate in most months coming in between 15\%-20\%.

Switching to Figure 2, we can see that asylees from countries associated with the attacks were much more likely to be granted asylum both prior to the attacks and after the attacks. However, just as in Figure 1 the gap appears to shrink after the attacks. For asylees from associated countries, 
prior to the attacks, the average asylum grant rate for several months broke $60 \%$ and only once was below $30 \%$. After the attacks, several months fell below $30 \%$ and no months broke $70 \%$. As with Figure 1, there appears to be an upward trend in the average monthly asylum grant rate prior to the attacks. Afterward, the growth rate levels out for asylees from nonassociated countries and appears to be slightly negative for those from associated countries. The results for asylees from associated countries are noisier than those for non-associated countries, possibly because of the smaller number of observations for asylees from associated countries.

In both figures, the trends for asylees from Muslim-majority countries and associated countries appear to track the trends for asylees not from Muslim-majority or associated countries very closely. More formally, Appendix Table A1 shows the estimation of Equation 1 with the inclusion of a linear time trend interacted with a dummy variable indicating if the asylee is from a Muslim-majority country. The full suite of controls are also included and standard errors are clustered at the country of origin. The results indicate that there is no significant difference in the pre-treatment trends for asylum approval rating between asylees from Muslim-majority countries and those not from Muslim-majority countries. Together, these provide evidence that our choice of control groups represent appropriate counterfactuals prior to the Sept. 11, 2001 attacks and would continue to do so afterward. We delay our discussion of our placebo treatment to Section 6.

Given the large degree of heterogeneity in judge grant rates, it is crucial for our identification that there is no sorting of cases for asylees from Muslim-majority countries to judges that are particularly lenient or severe. Appendix Table A2 presents the results from a regression of a judge stringency measure (created by calculating the leave-one-out mean grant rates for each judge) on a dummy variable that equals 1 if an asylee is from a Muslim-majority country and 0 otherwise, while controlling for court fixedeffects. If cases are randomly assigned, the point estimate should be close to zero and that is exactly what we find.

There may be concerns that Sept. 11, 2001 and March 11, 2004 resulted in a change in the composition of asylum applicants. This would be an issue if the change is more pronounced for Muslim applicants, possibly in anticipation of potential backlash. This is not an issue for our main specification since we restrict the sample only to cases occurring six months before and after Sept. 11, 2001. The Immigration and Nationality Act requires that a decision be made on applications within 180 days of filing, though in prac- 
tice backlogs are much longer than this. According to the Transactional Records Access Clearinghouse, a data gathering, distribution, and research organization housed at Syracuse University, the average wait time for the entire U.S. across all nationalities ranged from a low of 380 days in 2000 to a high of 422 days in 2003 (TRAC (2018)), while the average processing time ranged from 234 days in 2001 to 283 days in 2004 (TRAC (2018)). As a consequence, the hearings in our sample will correspond to applications filed before Sept. 11, 2001 and March 11, 2004 thus avoiding any potential bias from compositional changes in the applicant pool. We also note that due to data limitations, we are only able to conduct 3 month and 6 month windows around March 11, 2004. ${ }^{13}$

Additionally, we include Appendix Table A3 which regresses whether an asylee is from a Muslim-majority country on a binary variable that equals 1 if the case is heard after Sept. 11, 2001. The estimated coefficient is statistically insignificant, meaning that hearings occurring after the attacks are no more likely to be for asylees from Muslim-majority countries than are those prior to the attacks.

Triple Differences - We supplement our main analysis by investigating how the effect estimated in Equation 1 varies across immigration judges appointed during a Republican or Democrat presidency, employing a tripledifferences (DDD) research design ${ }^{14}$. We estimate

$$
\begin{aligned}
& y_{i t j}=\alpha+\beta \text { Muslim }_{i}+\delta{\text { Post } 911_{t}+\zeta \text { Muslim }_{i} \times \text { JudgeChar } j+}
\end{aligned}
$$

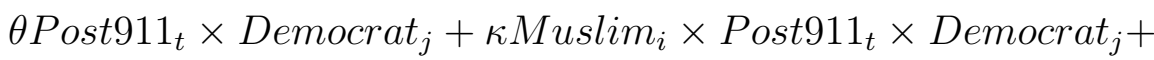

$$
\begin{aligned}
& \gamma \text { Muslim }_{i} \times{\text { Post } 911_{t}+X_{i}^{\prime} \eta+V_{j}^{\prime} \eta+\text { Otemperature }}_{c t}+\tau_{c}+\omega_{m}+\rho_{c m}+\epsilon_{i t j}
\end{aligned}
$$

where $V_{j}^{\prime}$ is a vector of judge specific variables including gender, and dummies for between 0-5 years, 6-10 years and more than 10 years of experience as of Sept. 11, 2001. Democrat ${ }_{j}$ is a binary variable that equals one if the judge was appointed during a Democrat presidency and zero if appointed during a Republican presidency. For example, we compare the difference in asylum grant rates for asylees from Muslim-majority countries (treated) to asylum grant rates for asylees from other countries (control),

\footnotetext{
${ }^{13}$ We are seven days short of fully having 6 month windows around March 11, 2004.

${ }^{14}$ For other examples of triple-differences see, for example, Brodeur and Connolly (2013), Jayachandran and Lleras-Muney (2009), or Carr and Doleac (2018)
} 
across Democrat (treated) and Republican (control) judges, before (control) and after Sept. 11, 2001 (treated). Our coefficient of interest in this model is $\kappa$, which shows the effect of the DDD interaction term, Muslim ${ }_{i} \times$

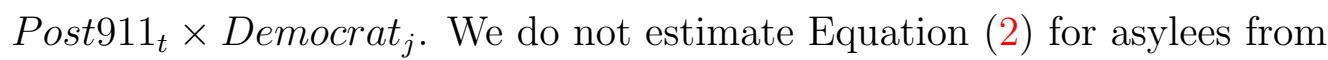
countries associated with the attacks due to sample size concerns. All other components are defined as in Equation (1).

\section{Results}

In this section, we first estimate the effects of Sept. 11, 2001 and March 11, 2004 on granting rates for applicants from Muslim-majority countries and countries associated with the attacks. We then estimate how the effect of Sept. 11, 2001 for Muslim-majority countries and associated countries varies by a judge's political affiliation. We conclude this section with robustness checks.

\subsection{Difference-in-Differences}

Table 2 presents OLS estimates of Equation (1) for asylees from a Muslimmajority country whose case was heard within 180 days before or after Sept. 11, 2001. What clearly emerges is that Sept. 11, 2001 is associated with a large decrease in the likelihood applicants from Muslim-majority countries are granted asylum. As noted in Section 5, we restrict our sample around the attacks on Sept. 11, 2001 in order to help address concerns about changes in the composition of applicants, perhaps reflecting strategic behavior in response to the attacks. Consequently, the time period is March 15, 2001 to March 9, 2002 (180 days before and after). The dependent variable is a dummy that equals one if asylum is granted and zero otherwise. The sample size is 48,340 observations (i.e., cases). As mentioned in Section 5 , we report standard errors clustered by asylee country of origin in parentheses. Appendix Table A4 presents the estimated coefficients for control variables.

Column 1 presents the simple differences of an applicant being from a Muslim-majority country and having their case heard after Sept. 11, 2001. We show that prior to the attacks, applicants from Muslim-majority countries, in comparison to other applicants, were significantly more likely to receive asylum (coeff. of 0.112 ). The dummy Post911 $t$, which indicates whether the case was heard after Sept. 11, 2001, is negative and statistically significant at the $1 \%$ level. The estimate suggests that the attacks decreased the likelihood to receive asylum by about 2 percentage points (pp). 
Column 2 adds our coefficient of interest, $\gamma$, in the third row. We find that the Sept. 11, 2001 attacks resulted in a 3.8 percentage point decrease in the likelihood that applicants from Muslim-majority countries are granted asylum. Column 3 adds applicant and temperature controls along with judge and city fixed effects, while columns 4 and 5 add month fixed effects and city-month fixed effects, respectively. Applicant controls include detention status, application type (affirmative or defensive), and legal representation, while temperature is the mean temperature in the city of the hearing from $6 \mathrm{am}$ to $4 \mathrm{pm}$ on the day of the hearing. ${ }^{15}$ Our estimates are remarkably stable (3.2-3.8pp throughout) and are statistically significant at the $1 \%$ level across all specifications.

Our estimates suggest that Sept. 11, 2001 caused a 11.3\%-13.4\% drop in the likelihood that asylees from Muslim-majority countries receive asylum. In our sample, the mean grant rant for asylees from Muslim-majority countries is $28.3 \%$ (standard deviation 45.1 ). In order to gain insight into the magnitude of our estimates, we compare them to other studies. For instance, Heyes and Saberian (2019) find that a one standard deviation increase in case-day temperature reduces asylum grant rates by $8.56 \%$. Eren and Mocan (2018) find that surprise loses of a football team from that judge's former college result in juvenile sentences that are $6 \%$ longer. Philippe and Ouss (2018) find that french jury trials occurring after news on crime increases sentence length by $2.4 \%$.

Table 3 presents the results of Equation (1) for asylees from a country associated with the Sept. 11, 2001 attacks whose case was heard within 180 days before or after the attacks. The structure of the table is the same as in Table 2. Once again, the attacks result in a large decrease in the likelihood of granted asylum and in fact the estimates here are much larger. As before, column 1 presents the simple differences of an applicant having their case heard after the attacks or of being from an associated country. We find that those from an associated country are significantly more likely to receive asylum. We also find a very similar estimate of the effect of an applicant's case being heard after Sept. 11, 2001.

The estimates in columns 2-4 suggest that the Sept. 11, 2001 attacks caused a significant decline in the likelihood of applicants from associated countries to receive asylum. The estimates range from $6 \mathrm{pp}$ to $9.9 \mathrm{pp}$ and are statistically significant at the $10 \%$ level in our preferred specification.

\footnotetext{
${ }^{15}$ As discussed in Section 5, we control for these additional variables to ensure that our estimates are not picking up compositional changes in the pool of applicants in response to the events of September 11, 2001.
} 
It is important to emphasize that because there are relatively few asylees from attack associated countries, our estimates are relatively imprecise.

Table 4 contains the OLS estimates of Equation (1) for asylees from a Muslim-majority country whose case was heard within 180 days of the March 11, 2004 attacks in Madrid. The structure of the table is the same as Tables 2 and 3. Unlike our estimates for the Sept. 11, 2001 attacks, our estimates in column 1 of the effects of applicants being from Muslimmajority countries or for having a case heard after the attacks are not statistically significant at conventional levels. Columns 2-4 again suggest that we find an effect of the Madrid attacks of between 2.2pp and 2.9pp. These estimated effects are very similar in magnitude to those of the Sept. 11 attacks. ${ }^{16}$ It may be surprising that the magnitude of the effect of the Madrid attacks on immigration judges is so similar to that of the Sept. 11 attacks which took place on American soil. One possibility is that immigration judges in America became more sensitive to terrorism related shocks, perhaps in part due to the political climate and perception of the risks and threat of terrorism post Sept. 11, 2001.

\subsection{Robustness Checks and Placebo Test}

Table 5 explores the sensitivity of our findings to alternative choices of preand post-Sept. 11, 2001 periods. The sample window varies from 3 months (90 days) to 12 months (365 days) before and after Sept. 11, 2001. Columns 1-4 correspond to applicants from Muslim-majority countries and columns 5-8 correspond to applicants from countries associated with the attacks. Each column includes all applicant and temperature controls along with judge, city, month, and city-month fixed effects. Column 2 is the same as column 4 of Table 2 and column 6 is a repetition of column 4 in Table 3. The results suggest two main things: (1) the estimated effect size for applicants from Muslim-majority countries is in the same ballpark across these different windows; and (2) the sample size issues mentioned in the previous section have a dramatic effect on the precision of the estimates for attack associated countries across different windows.

Additionally, Appendix Tables A5 and A6 present Logit and Probit results for Equation (1) for asylees from Muslim-majority countries whose

\footnotetext{
${ }^{16}$ We also estimate this specification for the Madrid attacks with the treatment definition being changed to asylees sharing a country with the attackers (Morocco and Tunisia). Our estimated coefficients for the interaction term are negative but not statistically significant at conventional levels. However, the Madrid attacks were perpetrated by individuals linked to only two countries and thus we are quite underpowered for this analysis.
} 
case was heard within 180 days before or after Sept. 11, 2001. These tables are replications of Table 2. The estimates provided are marginal effects and are very similar to those found in Table 2 . We find an effect of a magnitude around $2.2 \mathrm{pp}-2.8 \mathrm{pp}$ that is statistically significant at the $5 \%$ level and that is robust to adding or removing controls and fixed effects. These tables present a 6 month (180 day) window, but the results are robust across all windows.

Appendix Tables A7, A8, and A9 contain the results of placebo tests using Equation (1) for asylees from Muslim-majority countries and associated countries whose case was heard within 180 days before or after Sept. 11, 2000, 2002, and 2003, respectively. Columns 1-4 correspond to applicants from Muslim-majority countries and columns 5-8 correspond to applicants from countries associated with the attacks. Because there were no attacks on Sept. 11, 2000, 2002, or 2003 the DD interaction terms should be zero. In fact, we see that these estimated effects are not significantly different from zero and are unaffected by including or excluding applicant and temperature controls and judge, month, and city fixed effects. While this table presents a 6 month (180 day) window, the results are robust across all windows. These placebo tests combined with our formal pre-trend test for divergence in Table A1 and visual inspection of the trends in Figures 1 and 2 suggest that non-Muslim asylees are an appropriate control group.

Appendix Table A10 produces the results of a placebo test using Equation (1) for asylees from Muslim-majority countries whose case was heard within 180 days of March 11, 2003. Again, we expect to see that the DD interaction term should be 0 as there is no attack on March 11, 2003. We do in fact see that the estimated coefficient is not statistically different from 0 and robust to the inclusion or exclusion of controls and fixed effects.

Appendix Table A11 presents the same results as Table 2 but excludes withdrawn and dismissed cases. The estimated coefficient of interest is in the same direction and very close in magnitude to that presented in Table 2 and is statistically significant at the $5 \%$ level. Our other estimates using dismissed and withdrawn cases are similarly unchanged from those excluding them.

Appendix Table A12 provides estimates for Equation (1) raising the threshold for determining that a country is a Muslim-majority country from $50 \%$ to $75 \%$. The estimates have the same direction and similar magnitude as those in Table 2 and the estimate in our preferred specification (column 5 ) is statistically significant at the $5 \%$ level. 


\subsection{Triple-Differences}

Table 6 presents the results of Equation (2) for asylees from Muslimmajority countries. As in the previous DD analysis, the first two differences remain before and after Sept. 11, 2001 and whether or not the applicant is from a Muslim-majority country. The third difference is whether or not the case is heard by a judge who was appointed during a Democrat presidency. It is unclear whether there is a differential in the effect of Sept. 11, 2001 by the appointing political party of the judge given that approval of the Patriot Act was heavily bipartisan. Furthermore, the majority of Democratic Senators also approved the Authorization for Use of Military Force Against Iraq Resolution.

As in Table 5, we allow the sample window to vary from 3 months (90 days) to 12 months (365 days) before and after Sept. 11, 2001. All estimates include applicant, judge and temperature controls as well as city, month, and city-month fixed effects with standard errors clustered at the asylee's country of origin. Our results suggest that the differential effect of Sept. 11, 2001 on Muslim-majority country asylees does not vary by the appointing political party of the judge. Estimates are not statistically significant across any of the windows around the attacks and the point estimates of the coefficients are quite small. These results are in contrast with recent work by Cohen and Yang (2019) who find that the appointing political party of federal judges influences judge decision making. It is worth emphasizing here, however, that we are measuring differences in judge responses to Sept. 11, 2001 along political affiliation and not differences in asylum approval along political affiliation.

\section{Conclusion}

Using the universe of asylum applications in the U.S. we investigated the effect of Islamic terrorism on granting rates for asylees from Muslim-majority countries in comparison to those from other countries. We find asylees from Muslim-majority countries were 3.2 percentage points less likely to be granted asylum in the aftermath of Sept. 11, 2001. For asylees from countries associated with the Sept. 11, 2001 attacks (Egypt, Lebanon, Saudi Arabia, United Arab Emirates) the effect is even more pronounced - they were 6-9.9 percentage points less likely to be granted asylum than those from other countries, however these estimates are relatively imprecise due to the small number of asylees from attack associated countries. We also find that the events of March 11, 2004 resulted in a 2.9 percentage point re- 
duction in the likelihood that asylees from Muslim-majority countries were granted asylum. These results are robust to applicant and temperature controls, judge, city, month, and city-month fixed effects, as well as alternative estimation methods. Additionally, we do not find evidence of differences in the differential effects of Sept. 11, 2001 on asylees from Muslim-majority countries across judge political affiliation.

Our results are consistent with the emerging literature documenting the influence of emotions on decision making. These findings are of interest to policy makers in evaluating the performance of immigration judges and in preparing for potential consequences of terrorism for the justice system. Additionally, these findings are of interest in contributing to the research enumerating the consequences of terrorism and in particular the legacy of Sept. 11, 2001. 


\section{References}

Abadie, A. and Gardeazabal, J.: 2003, The Economic Costs of Conflict: A Case Study of the Basque Country, American Economic Review 93(1), 113-132.

Alesina, A. and La Ferrara, E.: 2014, A Test of Racial Bias in Capital Sentencing, American Economic Review 104(11), 3397-3433.

Andrews, R. H., Gans, J., Kruse, M. and Lowry, R.: 2019, 'When Deported, You Become Nothing'.

URL: https://www.politico.com/magazine/story/2019/04/19/displacedpuebla-deportation-immigration-new-york-photos-226657

Anwar, S., Bayer, P. and Hjalmarsson, R.: 2012, The Impact of Jury Race in Criminal Trials, Quarterly Journal of Economics 127(2), 1017-1055.

Avdan, N.: 2014, Do Asylum Recognition Rates in Europe Respond to Transnational Terrorism? The Migration-Security Nexus Revisited, European Union Politics 15(4), 445-471.

Becker, G. S. and Rubinstein, Y.: 2011, Fear and the Response to Terrorism: An Economic Analysis. CEP Discussion Paper 1079.

Beland, L.-P. and Brent, D. A.: 2018, Traffic and Crime, Journal of Public Economics 160, 96-116.

Bisin, A., Patacchini, E., Verdier, T. and Zenou, Y.: 2008, Are Muslim Immigrants Different in Terms of Cultural Integration?, Journal of the European Economic Association 6(2-3), 445-456.

Blomberg, S. B., Hess, G. D. and Orphanides, A.: 2004, The Macroeconomic Consequences of Terrorism, Journal of Monetary Economics 51(5), 1007-1032.

Brodeur, A.: 2018, The Effect of Terrorism on Employment and Consumer Sentiment: Evidence from Successful and Failed Terror Attacks, American Economic Journal: Applied Economics 10(4), 246-82.

Brodeur, A. and Connolly, M.: 2013, Do Higher Child Care Subsidies Improve Parental Well-Being? Evidence from Quebec's Family Policies, Journal of Economic Behavior \& Organization 93, 1-16. 
Brodzinsky, S.: 2015, The migrants who fled violence for the US only to be sent back to their deaths.

URL: https://www.theguardian.com/world/2015/oct/12/deportationmigrants-flee-honduras-guatemala-salvador

Bulman, M.: 2018, Afghan father who sought refuge in UK 'shot dead by Taliban' after being deported by Home Office.

URL: https://www.independent.co.uk/news/uk/home-news/zainadinfazlie-deport-home-office-taliban-afghanistan-shot-dead-refugeea8536736.html

Cable News Network (CNN): 2006, Courts Told to Be Nicer to Immigrants. Online; accessed March 2018.

Card, D. and Dahl, G. B.: 2011, Family Violence and Football: The Effect of Unexpected Emotional Cues on Violent Behavior, Quarterly Journal of Economics 126(1), 103-143.

Carr, J. B. and Doleac, J. L.: 2018, Keep the Kids Inside? Juvenile Curfews and Urban Gun Violence, Review of Economics and Statistics 100(4), 609-618.

Cohen, A. and Yang, C. S.: 2019, Judicial Politics and Sentencing Decisions, American Economic Jounral: Economic Policy 11(1), 160-91.

Cornelissen, T. and Jirjahn, U.: 2012, September 11th and the Earnings of Muslims in Germany-The Moderating Role of Education and Firm Size, Journal of Economic Behavior \& Organization 81(2), 490-504.

Crain, N. V. and Crain, W. M.: 2006, Terrorized Economies, Public Choice 128(1-2), 317-349.

Danziger, S., Levav, J. and Avnaim-Pesso, L.: 2011, Extraneous Factors in Judicial Decisions, Proceedings of the National Academy of Sciences 108(17), 6889-6892.

Dávila, A. and Mora, M. T.: 2005, Changes in the Earnings of Arab Men in the US Between 2000 and 2002, Journal of Population Economics 18(4), 587-601.

Department of Justice: 2018a, About the Office. Executive Office for Immigration Review. Online; accessed August 2018. 
Department of Justice: 2018b, Immigration Judge. Executive Office for Immigration Review. Online; accessed March 2018.

Dreher, A., Gassebner, M. and Schaudt, P.: 2017, The Effect of Migration on Terror-Made at Home or Imported from Abroad? CEPR Discussion Paper 12062.

Elsayed, A. and De Grip, A.: 2018, Terrorism and the Integration of Muslim Immigrants, Journal of Population Economics 31(1), 45-67.

Eren, O. and Mocan, N.: 2018, Emotional Judges and Unlucky Juveniles, American Economic Journal: Applied Economics 10(3), 171-205.

Gould, E. D. and Klor, E. F.: 2016, The Long-Run Effect of 9/11: Terrorism, Backlash, and the Assimilation of Muslim Immigrants in the West, Economic Journal 126(597), 2064-2114.

Han, S., Lerner, J. S. and Keltner, D.: 2007, Feelings and Consumer Decision Making: The Appraisal-Tendency Framework, Journal of Consumer Psychology 17(3), 158-168.

Heyes, A. and Saberian, S.: 2019, Temperature and Decisions: Evidence from 207,000 Court Cases, American Economic Journal: Applied Economics 11(2), 238-65.

Jayachandran, S. and Lleras-Muney, A.: 2009, Life Expectancy and Human Capital Investments: Evidence from Maternal Mortality Declines, Quarterly Journal of Economics 124(1), 349-397.

Johnson, E. J. and Tversky, A.: 1983, Affect, Generalization, and the Perception of Risk, Journal of Personality and Social Psychology 45(1), 2031.

Kaushal, N., Kaestner, R. and Reimers, C.: 2007, Labor Market Effects of September 11th on Arab and Muslim Residents of the United States, Journal of Human Resources 42(2), 275-308.

Lerner, J., Gonzalez, R., Small, D. and Fischhoff, B.: 2003, Effects of Fear and Anger on Perceived Risks of Terrorism: A National Field Experiment, Psychological Science 14(2), 144-150.

Lerner, J. S., Li, Y., Valdesolo, P. and Kassam, K. S.: 2015, Emotion and Decision Making, Annual Review of Psychology 66(1), 799-823. 
Liptak, A.: 2005, Courts Criticize Judges' Handling of Asylum Cases. The New York Times. Online; accessed March 2018.

Mason, P. L. and Matella, A.: 2014, Stigmatization and Racial Selection After September 11, 2001: Self-Identity Among Arab and Islamic Americans, IZA Journal of Migration 3(1), 20.

McConnell, B. and Rasul, I.: 2019, Contagious Animosity in the Field: Evidence from the Federal Criminal Justice System. Working Paper.

Miller, B., Keith, L. C. and Holmes, J. S.: 2015, Immigration Judges and U.S. Asylum Policy, University of Pennsylvania Press.

National Association of Immigration Judges: 2011, Statement of National Association of Immigration Judges Before the Senate Committee on the Judiciary on "Improving Efficiency and Ensuring Justice in the Immigration Court System".

Philippe, A. and Ouss, A.: 2018, "No Hatred or Malice, Fear or Affection": Media and Sentencing, Journal of Political Economy 126(5), 2134-2178.

Ramji-Nogales, J., Schoenholtz, A. I. and Schrag, P. G.: 2007, Refugee roulette: Disparities in asylum adjudication, Stanford Law Review 60(2), 295-411.

Ratcliffe, A. and von Hinke Kessler Scholder, S.: 2015, The London Bombings and Racial Prejudice: Evidence from the Housing and Labor Market, Economic Inquiry 53(1), 276-293.

Refugee, Asylum, and International Operations Directorate: 2016, Affirmative Asylum Procedures Manual, Technical report.

Shayo, M. and Zussman, A.: 2011, Judicial Ingroup Bias in the Shadow of Terrorism, Quarterly Journal of Economics 126(3), 1447-1484.

Stillman, S.: 2018, When Deportation Is a Death Sentence.

URL: $\quad$ https://www.newyorker.com/magazine/2018/01/15/whendeportation-is-a-death-sentence

TRAC: 2008, TRAC Immigration Judge Reports: Frequently Asked Questions. Transactional Records Access Clearinghouse, Syracuse University.

TRAC: 2018, Immigration Court Backlog Tool: Pending Cases and Length of Wait in Immigration Courts. Transactional Records Access Clearinghouse, Syracuse University. 
Tversky, A. and Kahneman, D.: 1973, Availability: A Heuristic for Judging Frequency and Probability, Cognitive Psychology 5(2), 207-232. 
Figure 1: Average Monthly Relief Rates: Muslim-Majority Countries v. Other Applicants

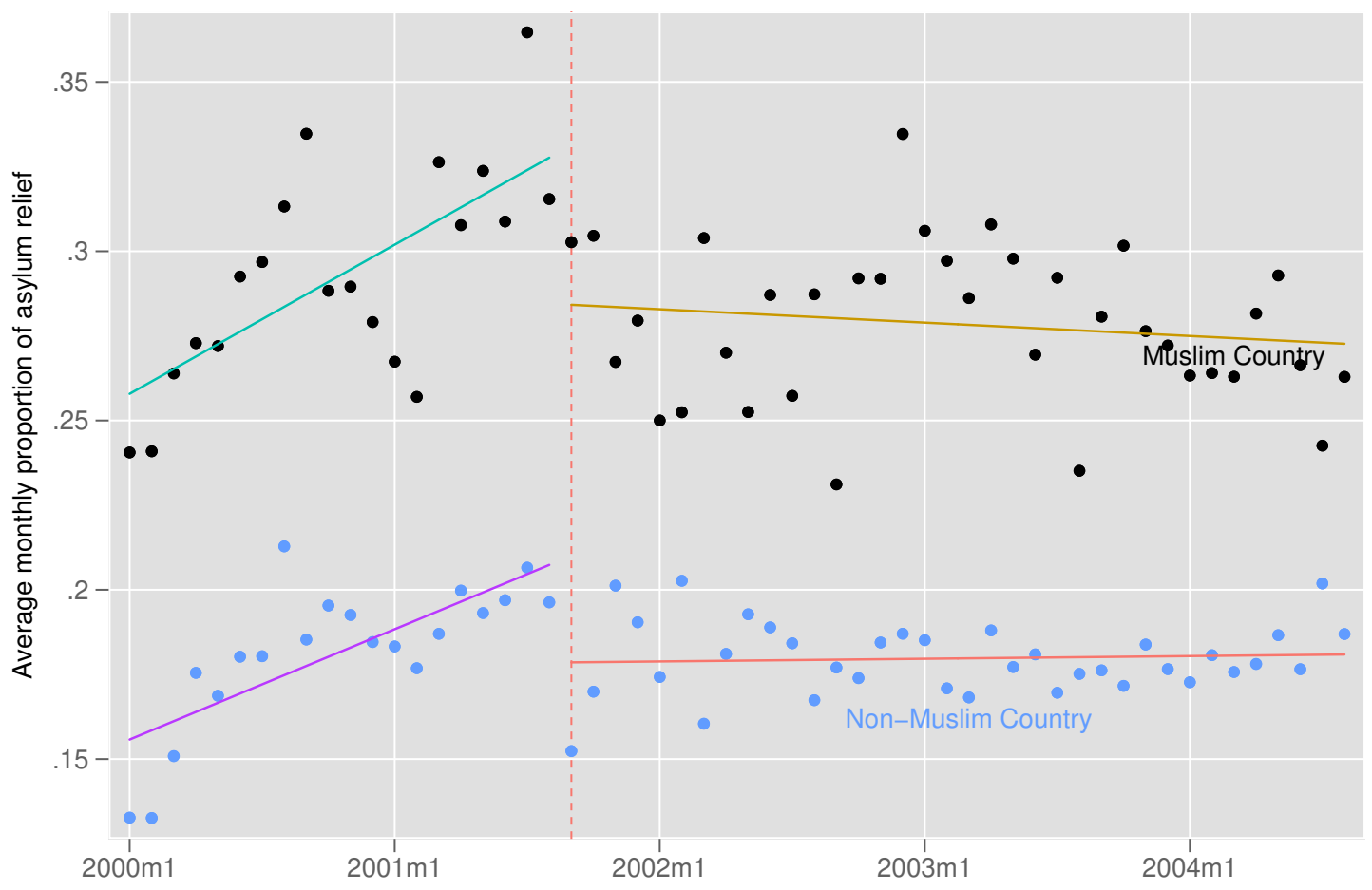

Figure 2: Average Monthly Relief Rates: Attack Associated Countries and Non-Attack Associated Countries

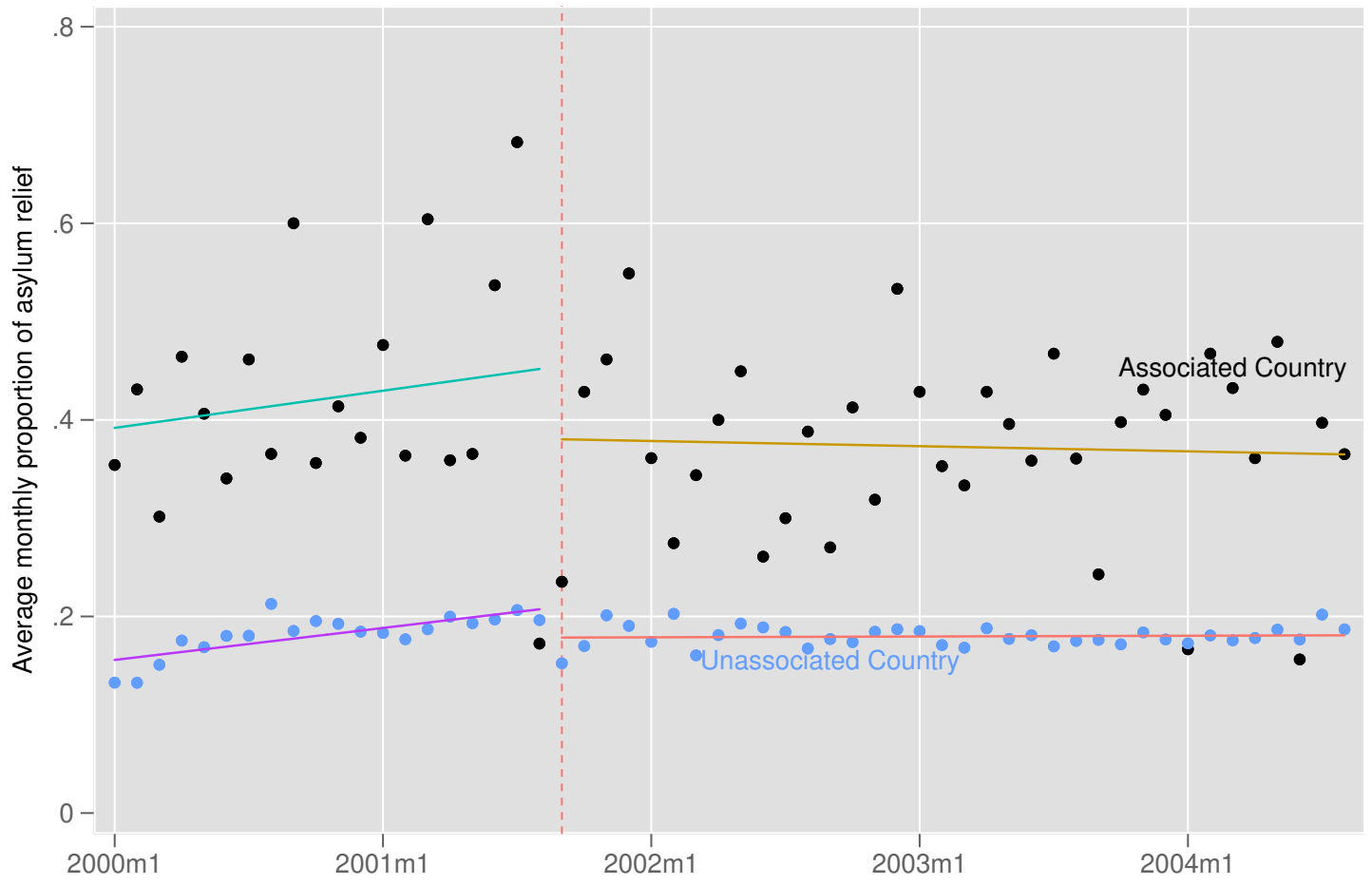




\begin{tabular}{lcc}
\hline & & \\
& Mean & Std. Dev. \\
\hline Outcomes & & \\
Applicant Granted Any Relief & 0.183 & 0.387 \\
& & \\
Applicants' Characteristics & & \\
Asylee from Muslim-Majority Country & 0.015 & 0.123 \\
Asylee from Sept. 11, 2001 Associated Country & 0.015 & 0.123 \\
Defensive Application & 0.299 & 0.458 \\
Has Legal Representation & 0.803 & 0.398 \\
Location is DOC, Detention Center or Prison & 0.077 & 0.267 \\
& & \\
Judges' Characteristics & & \\
Judge Appointed During Democrat Presidency & 0.709 & 0.454 \\
Judge is Female & 0.369 & 0.482 \\
0-5 Year of Experience & 0.347 & 0.476 \\
6-10 Years of Experience & 0.440 & 0.496 \\
More 10 Years of Experience & 0.213 & 0.409 \\
\hline Observations & 224,436 & \\
\hline
\end{tabular}

Note: Authors' calculations. See Section 4 for more details. The time period is January 2000-August2004.

Table 2: Effect of Sept. 11, 2001 on Any Relief Granted: Muslim-Majority Countries

\begin{tabular}{lccccc}
\hline & $(1)$ & $(2)$ & $(3)$ & $(4)$ & $(5)$ \\
\hline Asylee from Muslim-maj. country & 0.112 & 0.131 & 0.121 & 0.121 & 0.120 \\
& $(0.048)$ & $(0.048)$ & $(0.034)$ & $(0.034)$ & $(0.034)$ \\
After Sept. 11, 2001 & -0.020 & -0.013 & -0.008 & -0.005 & -0.009 \\
& $(0.008)$ & $(0.009)$ & $(0.008)$ & $(0.011)$ & $(0.011)$ \\
Muslim-maj. country & & -0.038 & -0.036 & -0.036 & -0.032 \\
After Sept. 11, 2001 & & $(0.014)$ & $(0.012)$ & $(0.012)$ & $(0.011)$ \\
& & & & \\
Observations & 48,340 & 48,340 & 48,340 & 48,340 & 48,340 \\
R-squared & 0.012 & 0.012 & 0.174 & 0.174 & 0.186 \\
Applicant Controls & & & $\checkmark$ & $\checkmark$ & $\checkmark$ \\
Temperature & & & $\checkmark$ & $\checkmark$ & $\checkmark$ \\
Judge FE & & & $\checkmark$ & $\checkmark$ & $\checkmark$ \\
City FE & & & & $\checkmark$ & $\checkmark$ \\
Month FE & & & & & $\checkmark$ \\
City $\times$ Month FE & & & $\checkmark$ & $\checkmark$ \\
\hline
\end{tabular}

Note: This table shows OLS estimates of Equation (1). The unit of observation is a case. The dependent variable is a dummy that equals one if asylum is granted and zero otherwise. The time period is March 15, 2001 to March 9, 2002. Applicant controls include application type, detention

status, and legal representation. Judge, city, month, and city-month fixed effects are included.

Temperature is the mean temperature on the day of the hearing from $6 \mathrm{am}-4 \mathrm{pm}$. Standard errors are clustered by country of origin and are shown in parentheses. 
Table 3: Effect of Sept. 11, 2001 on Any Relief Granted: Attack Associated Countries

\begin{tabular}{lccccc}
\hline & $(1)$ & $(2)$ & $(3)$ & $(4)$ & $(5)$ \\
\hline Asylee from associated country & 0.249 & 0.303 & 0.252 & 0.251 & 0.248 \\
& $(0.056)$ & $(0.048)$ & $(0.034)$ & $(0.034)$ & $(0.034)$ \\
After Sept. 11, 2001 & -0.014 & -0.013 & -0.009 & -0.010 & -0.017 \\
& $(0.009)$ & $(0.009)$ & $(0.008)$ & $(0.012)$ & $(0.012)$ \\
Associated country $\times$ & & -0.099 & -0.064 & -0.062 & -0.060 \\
After Sept. 11, 2001 & & $(0.031)$ & $(0.027)$ & $(0.026)$ & $(0.026)$ \\
Observations & & & & \\
R-squared & 39,882 & 39,882 & 39,882 & 39,882 & 39,882 \\
Applicant Controls & 0.006 & 0.007 & 0.173 & 0.173 & 0.186 \\
Temperature & & & $\checkmark$ & $\checkmark$ & $\checkmark$ \\
Judge FE & & & $\checkmark$ & $\checkmark$ & $\checkmark$ \\
City FE & & & $\checkmark$ & $\checkmark$ & $\checkmark$ \\
Month FE & & & & $\checkmark$ & $\checkmark$ \\
City × Month FE & & & & & $\checkmark$ \\
\hline
\end{tabular}

Note: This table shows OLS estimates of Equation (1). The unit of observation is a case. The dependent variable is a dummy that equals one if asylum is granted and zero otherwise. The time period is March 15, 2001 to March 9, 2002. Applicant controls include application type, detention

status, and legal representation. Judge, city, month, and city-month fixed effects are included.

Temperature is the mean temperature on the day of the hearing from $6 \mathrm{am}-4 \mathrm{pm}$. Standard errors are clustered by country of origin and are shown in parentheses.

Table 4: Effect of March 11, 2004 on Any Relief Granted: Muslim-Majority Countries

\begin{tabular}{lccccc}
\hline & $(1)$ & $(2)$ & $(3)$ & $(4)$ & $(5)$ \\
\hline Asylee from Muslim-maj. country & 0.092 & 0.102 & 0.047 & 0.048 & 0.048 \\
& $(0.060)$ & $(0.061)$ & $(0.035)$ & $(0.036)$ & $(0.036)$ \\
After March 11, 2004 & 0.006 & 0.010 & 0.008 & 0.003 & 0.004 \\
& $(0.007)$ & $(0.008)$ & $(0.006)$ & $(0.010)$ & $(0.009)$ \\
Muslim-maj. country & & -0.022 & -0.026 & -0.027 & -0.029 \\
After March 11, 2004 & & $(0.012)$ & $(0.011)$ & $(0.011)$ & $(0.010)$ \\
& & & & & \\
Observations & 64,393 & 64,393 & 64,393 & 64,393 & 64,393 \\
R-squared & 0.008 & 0.008 & 0.207 & 0.207 & 0.218 \\
Applicant Controls & & & $\checkmark$ & $\checkmark$ & $\checkmark$ \\
Temperature & & & $\checkmark$ & $\checkmark$ & $\checkmark$ \\
Judge FE & & & $\checkmark$ & $\checkmark$ & $\checkmark$ \\
City FE & & & & $\checkmark$ & $\checkmark$ \\
Month FE & & & & & $\checkmark$ \\
City $\times$ Month FE & & & $\checkmark$ & $\checkmark$ \\
\hline No: Tis tan & & & & $\checkmark$ \\
\hline
\end{tabular}

Note: This table shows OLS estimates of Equation (1). The unit of observation is a case. The dependent variable is a dummy that equals one if asylum is granted and zero otherwise. The time period is September 13, 2003 to August 31, 2004. Applicant controls include application type, detention status, and legal representation. Judge, city, month, and city-month fixed effects are included. Temperature is the mean temperature on the day of the hearing from $6 \mathrm{am}-4 \mathrm{pm}$. Standard errors are clustered by country of origin and are shown in parentheses. 
Table 5: Effect of Sept. 11, 2001 on Any Relief Granted: Muslim-Majority Countries and Attack Associated Countries

\begin{tabular}{|c|c|c|c|c|c|c|c|c|}
\hline & $\begin{array}{c}(1) \\
3 \text { Months }\end{array}$ & $\begin{array}{c}(2) \\
6 \text { Months }\end{array}$ & $\begin{array}{c}(3) \\
9 \text { Months }\end{array}$ & $\begin{array}{c}(4) \\
12 \text { Months }\end{array}$ & $\begin{array}{c}(5) \\
3 \text { Months }\end{array}$ & $\begin{array}{c}(6) \\
6 \text { Months }\end{array}$ & $\begin{array}{c}(7) \\
9 \text { Months }\end{array}$ & $\begin{array}{c}(8) \\
12 \text { Months }\end{array}$ \\
\hline Asylee from Muslim-maj. country & $\begin{array}{c}0.123 \\
(0.038)\end{array}$ & $\begin{array}{c}0.120 \\
(0.034)\end{array}$ & $\begin{array}{c}0.107 \\
(0.033)\end{array}$ & $\begin{array}{c}0.101 \\
(0.034)\end{array}$ & & & & \\
\hline After Sept. 11, 2001 & $\begin{array}{c}0.006 \\
(0.016)\end{array}$ & $\begin{array}{l}-0.009 \\
(0.011)\end{array}$ & $\begin{array}{l}-0.005 \\
(0.010)\end{array}$ & $\begin{array}{l}-0.006 \\
(0.008)\end{array}$ & $\begin{array}{c}0.010 \\
(0.016)\end{array}$ & $\begin{array}{l}-0.017 \\
(0.012)\end{array}$ & $\begin{array}{l}-0.003 \\
(0.010)\end{array}$ & $\begin{array}{l}-0.004 \\
(0.008)\end{array}$ \\
\hline $\begin{array}{l}\text { Muslim country } \times \\
\text { After Sept. } 11,2001\end{array}$ & $\begin{array}{l}-0.029 \\
(0.013)\end{array}$ & $\begin{array}{l}-0.032 \\
(0.011)\end{array}$ & $\begin{array}{l}-0.026 \\
(0.015)\end{array}$ & $\begin{array}{l}-0.022 \\
(0.018)\end{array}$ & & & & \\
\hline Applicant from associated country & & & & & $\begin{array}{c}0.286 \\
(0.037)\end{array}$ & $\begin{array}{c}0.248 \\
(0.034)\end{array}$ & $\begin{array}{c}0.235 \\
(0.034)\end{array}$ & $\begin{array}{c}0.225 \\
(0.039)\end{array}$ \\
\hline $\begin{array}{l}\text { Associated country } \times \\
\text { After Sept. 11, } 2001\end{array}$ & & & & & $\begin{array}{l}-0.099 \\
(0.048)\end{array}$ & $\begin{array}{l}-0.060 \\
(0.026)\end{array}$ & $\begin{array}{l}-0.045 \\
(0.012)\end{array}$ & $\begin{array}{l}-0.065 \\
(0.010)\end{array}$ \\
\hline Observations & 23,104 & 48,340 & 73,527 & 102,509 & 19,126 & 39,882 & 60,589 & 84,617 \\
\hline R-squared & 0.191 & 0.186 & 0.179 & 0.172 & 0.195 & 0.186 & 0.182 & 0.177 \\
\hline Applicant Controls & $\checkmark$ & $\checkmark$ & $\checkmark$ & $\checkmark$ & $\checkmark$ & $\checkmark$ & $\checkmark$ & $\checkmark$ \\
\hline Temperature & $\checkmark$ & $\checkmark$ & $\checkmark$ & $\checkmark$ & $\checkmark$ & $\checkmark$ & $\checkmark$ & $\checkmark$ \\
\hline Judge FE & $\checkmark$ & $\checkmark$ & $\checkmark$ & $\checkmark$ & $\checkmark$ & $\checkmark$ & $\checkmark$ & $\checkmark$ \\
\hline City FE & $\checkmark$ & $\checkmark$ & $\checkmark$ & $\checkmark$ & $\checkmark$ & $\checkmark$ & $\checkmark$ & $\checkmark$ \\
\hline Month FE & $\checkmark$ & $\checkmark$ & $\checkmark$ & $\checkmark$ & $\checkmark$ & $\checkmark$ & $\checkmark$ & $\checkmark$ \\
\hline City $\times$ Month FE & $\checkmark$ & $\checkmark$ & $\checkmark$ & $\checkmark$ & $\checkmark$ & $\checkmark$ & $\checkmark$ & $\checkmark$ \\
\hline
\end{tabular}

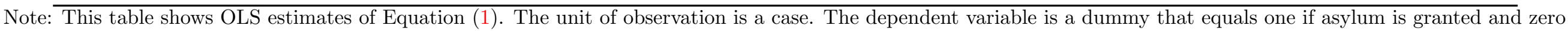

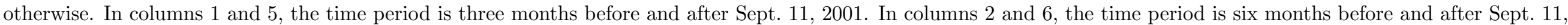

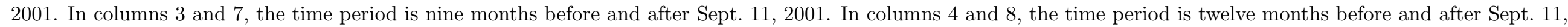

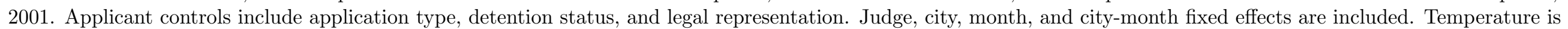
the mean temperature on the day of the hearing from $6 \mathrm{am}-4 \mathrm{pm}$. Standard errors are clustered by country of origin and are shown in parentheses. 
Table 6: Effect of Sept. 11, 2001 on Any Relief Granted: Muslim-Majority Countries by Judges Appointed during Democrat v. Republican Presidencies

\begin{tabular}{lcccc}
\hline & $(1)$ & $(2)$ & $(3)$ & $(4)$ \\
& 3 Months & 6 Months & 9 Months & 12 Months \\
\hline Muslim-maj. country $\times$ After $9 / 11$ & 0.016 & 0.002 & 0.019 & 0.003 \\
$\times$ Democrat & $(0.038)$ & $(0.025)$ & $(0.025)$ & $(0.026)$ \\
Observations & & & & \\
R-squared & 23,080 & 48,256 & 73,390 & 102,347 \\
Applicant Controls & 0.118 & 0.112 & 0.104 & 0.101 \\
Judge Controls & $\checkmark$ & $\checkmark$ & $\checkmark$ & $\checkmark$ \\
Temperature & $\checkmark$ & $\checkmark$ & $\checkmark$ & $\checkmark$ \\
City FE & $\checkmark$ & $\checkmark$ & $\checkmark$ & $\checkmark$ \\
Month FE & $\checkmark$ & $\checkmark$ & $\checkmark$ & $\checkmark$ \\
City $\times$ Month FE & $\checkmark$ & $\checkmark$ & $\checkmark$ & $\checkmark$ \\
\hline
\end{tabular}

Note: This table shows OLS estimates of Equation (2). The unit of observation is a case. The dependent variable is a dummy that equals one if asylum is granted and zero otherwise. The time period is March 15, 2001 to March 9, 2002. Applicant controls include application type, detention status, and legal representation. Judge controls include sex, experience, and political party of appointing administration. City fixed effects are included and temperature is the mean temperature on the day of the hearing from $6 \mathrm{am}-4 \mathrm{pm}$. All pairwise interactions are included in the regressions, but omitted from the tables. Standard errors are clustered by country of origin and are shown in parentheses. 


\section{APPENDIX: NOT FOR PUBLICATION}

Table A1: Test for Diverging Pre-Trends in Asylum Approval

\begin{tabular}{cc}
\hline & $(1)$ \\
\hline Muslim-maj. country $\times$ Time & 0.0000551 \\
& $(0.0000786)$
\end{tabular}

$\begin{array}{lc}\text { Observations } & 48,340 \\ \text { R-squared } & 0.1861 \\ \text { Applicant Controls } & \checkmark \\ \text { Temperature } & \checkmark \\ \text { Judge FE } & \checkmark \\ \text { City FE } & \checkmark \\ \text { Month FE } & \checkmark \\ \text { City } \times \text { Month FE } & \checkmark\end{array}$

Note: Coefficient is based on regressions of Equation (1) with the addition of a linear time trend and the interaction of the time trend and whether or not the asylee is from a Muslim-majority country. The dependent variable is a dummy that equals one if asylum is granted and zero otherwise. Applicant controls include application type, detention status, and legal representation. Judge, city, month, and city-month fixed effects are included. Temperature is the mean temperature on the day of the hearing from $6 \mathrm{am}-4 \mathrm{pm}$. Standard errors are clustered by country of origin and are shown in parentheses.

Table A2: Test for Random Assignment of Cases to Judges

\begin{tabular}{lc}
\hline & $(1)$ \\
\hline Asylee from Muslim-maj. country & 0.0000495 \\
& $(0.00000414)$ \\
Observations & 269,756 \\
R-squared & 0.431 \\
City FE & $\checkmark$ \\
\hline
\end{tabular}

Note: The dependent variable is a judge stringency measure created from leave-one-out mean grant rates for each judge. Coefficient presents results of regression of the judge stringency measure on a dummy variable that equals 1 if an asylee is from a Muslim-majority country and 0 otherwise. Court fixed-effects are included. 
Table A3: Test for Change in Likelihood of Muslim Cases of Judges

\begin{tabular}{lc}
\hline & $(1)$ \\
\hline & \\
After Sept. 11, 2001 & 0.012 \\
& $(0.013)$ \\
& \\
Observations & 48,340 \\
R-squared & 0.130 \\
Applicant Controls & $\checkmark$ \\
Temperature & $\checkmark$ \\
Judge FE & $\checkmark$ \\
City FE & $\checkmark$ \\
Month FE & $\checkmark$ \\
City $\times$ Month FE & $\checkmark$
\end{tabular}

Note: The dependent variable is a binary variable that equals 1 if an asylee is from a Muslim-majority country. Coefficient presents results of regression of this Muslim-country dummy on a dummy variable that equals 1 if the case is heard after Sept. 11, 2001 and 0 otherwise. Applicant controls include application type, detention status, and legal representation. Judge, city, month, and city-month fixed effects are included. Temperature is the mean temperature on the day of the hearing from $6 \mathrm{am}-4 \mathrm{pm}$.

Table A4: Full Estimation of the Effect of Sept. 11, 2001 on Any Relief Granted: Six Month Window

\begin{tabular}{lc}
\hline & $(1)$ \\
\hline Asylee from Muslim-maj. country & 0.120 \\
& $(0.034)$ \\
After Sept. 11, 2001 & -0.009 \\
Muslim-maj. country × After Sept. 11, 2001 & $(0.011)$ \\
& -0.032 \\
Defensive Application & $(0.011)$ \\
Has Legal Representation & -0.005 \\
& $(0.022)$ \\
Location is DOC, Detention centre, Jail, or Prison & 0.191 \\
Temperature & $(0.035)$ \\
& -0.005 \\
Observations & $(0.024)$ \\
R-squared & 0.008 \\
Applicant Controls & $(0.006)$ \\
Temperature & \\
Judge FE & 48,340 \\
City FE & 0.186 \\
Month FE & $\checkmark$ \\
City $\times$ Month FE & $\checkmark$ \\
\end{tabular}

Note: This table shows OLS estimates of Equation (1). The unit of observation is a case. The dependent variable is a dummy that equals one if asylum is granted and zero otherwise. The time period is March 15, 2001 to March 9, 2002. Judge, city, month, and city-month fixed effects are included. Temperature is the mean temperature on the day of the hearing from 6 am-4pm. Standard errors are clustered by country of origin and are shown in parentheses. 
Table A5: Logit Estimation of the Effect of Sept. 11, 2001 on Any Relief Granted: Six Month Window

\begin{tabular}{lccccc}
\hline & $(1)$ & $(2)$ & $(3)$ & $(4)$ & $(5)$ \\
\hline Asylee from Muslim-maj. country & 0.101 & 0.113 & 0.108 & 0.108 & 0.108 \\
& $(0.037)$ & $(0.035)$ & $(0.027)$ & $(0.027)$ & $(0.027)$ \\
After Sept. 11, 2001 & -0.020 & -0.014 & -0.010 & -0.006 & -0.012 \\
& $(0.008)$ & $(0.010)$ & $(0.008)$ & $(0.010)$ & $(0.012)$ \\
Muslim-maj. country & & -0.026 & -0.027 & -0.026 & -0.022 \\
After Sept. 11, 2001 & & $(0.014)$ & $(0.011)$ & $(0.010)$ & $(0.009)$ \\
Observations & & & & \\
Applicant Controls & 48,350 & 48,350 & 48,070 & 48,070 & 47,139 \\
Temperature & & & $\checkmark$ & $\checkmark$ & $\checkmark$ \\
Judge FE & & & $\checkmark$ & $\checkmark$ & $\checkmark$ \\
City FE & & & $\checkmark$ & $\checkmark$ & $\checkmark$ \\
Month FE & & & & $\checkmark$ & $\checkmark$ \\
City × Month FE & & & & $\checkmark$ \\
\hline
\end{tabular}

Note: This table shows Logit estimates of Equation (1). Marginal effects are reported. The unit of observation is a case. The dependent variable is a dummy that equals one if asylum is granted and zero otherwise. The time period is March 15, 2001 to March 9, 2002. Applicant controls include application type, detention status, and legal representation. Judge, city, month, and city-month fixed effects are included. Temperature is the mean temperature on the day of the hearing from $6 \mathrm{am}-4 \mathrm{pm}$. Standard errors are clustered by country of origin and are shown in parentheses.

Table A6: Probit Estimation of the Effect of Sept. 11, 2001 on Any Relief Granted: Six Month Window

\begin{tabular}{lccccc}
\hline & $(1)$ & $(2)$ & $(3)$ & $(4)$ & $(5)$ \\
\hline Asylee from Muslim-maj. country & 0.102 & 0.116 & 0.108 & 0.108 & 0.108 \\
& $(0.039)$ & $(0.037)$ & $(0.027)$ & $(0.027)$ & $(0.027)$ \\
After Sept. 11, 2001 & -0.020 & -0.014 & -0.010 & -0.006 & -0.011 \\
& $(0.008)$ & $(0.009)$ & $(0.008)$ & $(0.010)$ & $(0.012)$ \\
Muslim-maj. country & & -0.028 & -0.028 & -0.027 & -0.022 \\
After Sept. 11, 2001 & & $(0.014)$ & $(0.011)$ & $(0.011)$ & $(0.009)$ \\
Observations & & & & \\
Applicant Controls & 48,350 & 48,350 & 48,070 & 48,070 & 47,139 \\
Temperature & & & $\checkmark$ & $\checkmark$ & $\checkmark$ \\
Judge FE & & & $\checkmark$ & $\checkmark$ & $\checkmark$ \\
City FE & & & $\checkmark$ & $\checkmark$ & $\checkmark$ \\
Month FE & & & & $\checkmark$ & $\checkmark$ \\
City $\times$ Month FE & & & & $\checkmark$ \\
\hline
\end{tabular}

Note: This table shows Probit estimates of Equation (1). Marginal effects are reported. The unit of observation is a case. The dependent variable is a dummy that equals one if asylum is granted and zero otherwise. The time period is March 15, 2001 to March 9, 2002. Applicant controls include application type, detention status, and legal representation. Judge, city, month, and city-month fixed effects are included. Temperature is the mean temperature on the day of the hearing from $6 \mathrm{am}-4 \mathrm{pm}$. Standard errors are clustered by country of origin and are shown in parentheses. 
Table A7: Placebo Test using Sept. 11, 2000: Six Month Window

\begin{tabular}{|c|c|c|c|c|c|c|}
\hline & $(1)$ & $(2)$ & $(3)$ & $(4)$ & $(5)$ & $(6)$ \\
\hline Asylee from Muslim-maj. country & $\begin{array}{c}0.107 \\
(0.048)\end{array}$ & $\begin{array}{c}0.095 \\
(0.035)\end{array}$ & $\begin{array}{c}0.095 \\
(0.035)\end{array}$ & & & \\
\hline After Sept. 11, 2000 & $\begin{array}{c}0.008 \\
(0.006)\end{array}$ & $\begin{array}{c}0.019 \\
(0.006)\end{array}$ & $\begin{array}{c}0.038 \\
(0.015)\end{array}$ & $\begin{array}{c}0.008 \\
(0.006)\end{array}$ & $\begin{array}{c}0.017 \\
(0.006)\end{array}$ & $\begin{array}{c}0.043 \\
(0.015)\end{array}$ \\
\hline $\begin{array}{l}\text { Muslim-maj. country } \times \\
\text { After Sept. 11, } 2000\end{array}$ & $\begin{array}{l}-0.009 \\
(0.014)\end{array}$ & $\begin{array}{l}-0.015 \\
(0.012)\end{array}$ & $\begin{array}{l}-0.017 \\
(0.012)\end{array}$ & & & \\
\hline Applicant from associated country & & & & $\begin{array}{c}0.219 \\
(0.108)\end{array}$ & $\begin{array}{c}0.190 \\
(0.067)\end{array}$ & $\begin{array}{c}0.192 \\
(0.068)\end{array}$ \\
\hline $\begin{array}{l}\text { Associated country } \times \\
\text { After Sept. } 11,2000\end{array}$ & & & & $\begin{array}{c}0.022 \\
(0.021)\end{array}$ & $\begin{array}{c}0.025 \\
(0.012)\end{array}$ & $\begin{array}{c}0.022 \\
(0.013)\end{array}$ \\
\hline Observations & 47,672 & 47,672 & 47,672 & 39,342 & 39,342 & 39,342 \\
\hline R-squared & 0.010 & 0.161 & 0.162 & 0.006 & 0.167 & 0.167 \\
\hline Applicant Controls & & $\checkmark$ & $\checkmark$ & & $\checkmark$ & $\checkmark$ \\
\hline Temperature & & $\checkmark$ & $\checkmark$ & & $\checkmark$ & $\checkmark$ \\
\hline Judge FE & & $\checkmark$ & $\checkmark$ & & $\checkmark$ & $\checkmark$ \\
\hline City FE & & $\checkmark$ & $\checkmark$ & & $\checkmark$ & $\checkmark$ \\
\hline Month FE & & & $\checkmark$ & & & $\checkmark$ \\
\hline
\end{tabular}

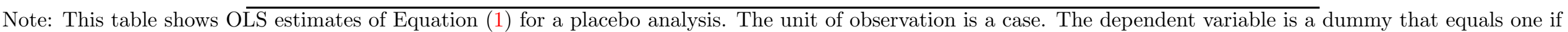

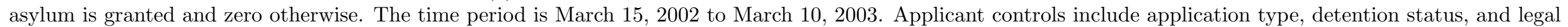

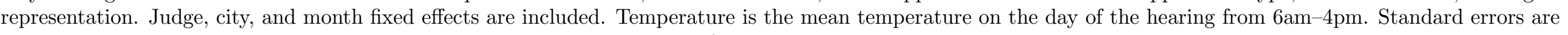
clustered by country of origin and are shown in parentheses. 
Table A8: Placebo Test using Sept. 11, 2002: Six Month Window

\begin{tabular}{|c|c|c|c|c|c|c|}
\hline & (1) & $(2)$ & $(3)$ & $(4)$ & $(5)$ & (6) \\
\hline Asylee from Muslim-maj. country & $\begin{array}{c}0.090 \\
(0.049)\end{array}$ & $\begin{array}{c}0.068 \\
(0.032)\end{array}$ & $\begin{array}{c}0.069 \\
(0.033)\end{array}$ & & & \\
\hline After Sept. 11, 2002 & $\begin{array}{c}0.000 \\
(0.006)\end{array}$ & $\begin{array}{l}-0.008 \\
(0.005)\end{array}$ & $\begin{array}{l}-0.002 \\
(0.010)\end{array}$ & $\begin{array}{c}0.000 \\
(0.006)\end{array}$ & $\begin{array}{l}-0.006 \\
(0.005)\end{array}$ & $\begin{array}{c}0.006 \\
(0.011)\end{array}$ \\
\hline $\begin{array}{l}\text { Muslim-maj. country } \times \\
\text { After Sept. 11, } 2002\end{array}$ & $\begin{array}{c}0.023 \\
(0.018)\end{array}$ & $\begin{array}{c}0.006 \\
(0.017)\end{array}$ & $\begin{array}{c}0.003 \\
(0.017)\end{array}$ & & & \\
\hline Asylee from associated country & & & & $\begin{array}{c}0.175 \\
(0.073)\end{array}$ & $\begin{array}{c}0.141 \\
(0.046)\end{array}$ & $\begin{array}{c}0.141 \\
(0.047)\end{array}$ \\
\hline $\begin{array}{l}\text { Associated country } \times \\
\text { After Sept. } 11,2002\end{array}$ & & & & $\begin{array}{c}0.024 \\
(0.030)\end{array}$ & $\begin{array}{l}-0.007 \\
(0.027)\end{array}$ & $\begin{array}{l}-0.009 \\
(0.026)\end{array}$ \\
\hline Observations & 58,914 & 58,914 & 58,914 & 49,132 & 49,132 & 49,132 \\
\hline R-squared & 0.010 & 0.197 & 0.197 & 0.004 & 0.206 & 0.207 \\
\hline Applicant Controls & & $\checkmark$ & $\checkmark$ & & $\checkmark$ & $\checkmark$ \\
\hline Temperature & & $\checkmark$ & $\checkmark$ & & $\checkmark$ & $\checkmark$ \\
\hline Judge FE & & $\checkmark$ & $\checkmark$ & & $\checkmark$ & $\checkmark$ \\
\hline City FE & & $\checkmark$ & $\checkmark$ & & $\checkmark$ & $\checkmark$ \\
\hline Month FE & & & $\checkmark$ & & & $\checkmark$ \\
\hline
\end{tabular}

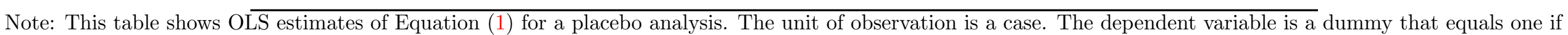
asylum is granted and zero otherwise. The time period is March 15, 200 to March 9, 2001. Applicant controls include application type, detention status, and legal

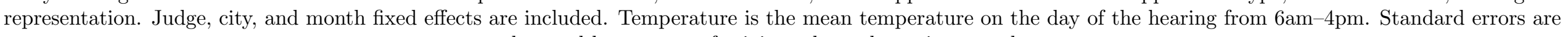
clustered by country of origin and are shown in parentheses. 
Table A9: Placebo Test using Sept. 11, 2003: Six Month Window

\begin{tabular}{|c|c|c|c|c|c|c|}
\hline & (1) & $(2)$ & $(3)$ & $(4)$ & $(5)$ & (6) \\
\hline Asylee from Muslim-maj. country & $\begin{array}{c}0.104 \\
(0.055)\end{array}$ & $\begin{array}{c}0.048 \\
(0.031)\end{array}$ & $\begin{array}{c}0.048 \\
(0.030)\end{array}$ & & & \\
\hline After Sept. 11, 2003 & $\begin{array}{l}-0.001 \\
(0.006)\end{array}$ & $\begin{array}{l}-0.007 \\
(0.007)\end{array}$ & $\begin{array}{c}0.002 \\
(0.011)\end{array}$ & $\begin{array}{l}-0.001 \\
(0.006)\end{array}$ & $\begin{array}{l}-0.009 \\
(0.008)\end{array}$ & $\begin{array}{l}-0.002 \\
(0.011)\end{array}$ \\
\hline $\begin{array}{l}\text { Muslim-maj. country } \times \\
\text { After Sept. 11, } 2003\end{array}$ & $\begin{array}{l}-0.000 \\
(0.017)\end{array}$ & $\begin{array}{c}0.003 \\
(0.016)\end{array}$ & $\begin{array}{c}0.002 \\
(0.016)\end{array}$ & & & \\
\hline Asylee from associated country & & & & $\begin{array}{l}0.227 \\
(0.061)\end{array}$ & $\begin{array}{c}0.174 \\
(0.030)\end{array}$ & $\begin{array}{c}0.174 \\
(0.029)\end{array}$ \\
\hline $\begin{array}{l}\text { Associated country } \times \\
\text { After Sept. } 11,2003\end{array}$ & & & & $\begin{array}{l}-0.019 \\
(0.074)\end{array}$ & $\begin{array}{l}-0.026 \\
(0.054)\end{array}$ & $\begin{array}{l}-0.026 \\
(0.054)\end{array}$ \\
\hline Observations & 69,792 & 69,792 & 69,792 & 58,923 & 58,923 & 58,923 \\
\hline R-squared & 0.010 & 0.187 & 0.187 & 0.004 & 0.191 & 0.191 \\
\hline Applicant Controls & & $\checkmark$ & $\checkmark$ & & $\checkmark$ & $\checkmark$ \\
\hline Temperature & & $\checkmark$ & $\checkmark$ & & $\checkmark$ & $\checkmark$ \\
\hline Judge FE & & $\checkmark$ & $\checkmark$ & & $\checkmark$ & $\checkmark$ \\
\hline City FE & & $\checkmark$ & $\checkmark$ & & $\checkmark$ & $\checkmark$ \\
\hline Month FE & & & $\checkmark$ & & & $\checkmark$ \\
\hline
\end{tabular}

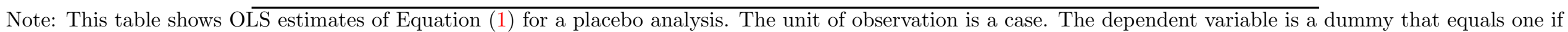

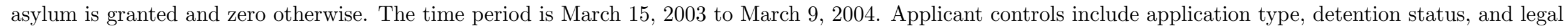

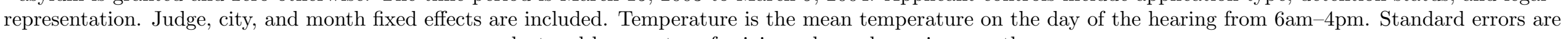
clustered by country of origin and are shown in parentheses. 
Table A10: Madrid Placebo Test using March 11, 2003: Six Month Window

\begin{tabular}{lccccc}
\hline & $(1)$ & $(2)$ & $(3)$ & $(4)$ & $(5)$ \\
\hline Asylee from Muslim-maj. country & 0.109 & 0.114 & 0.065 & 0.066 & 0.068 \\
& $(0.052)$ & $(0.050)$ & $(0.028)$ & $(0.028)$ & $(0.028)$ \\
After March 11, 2003 & -0.003 & -0.001 & 0.003 & 0.009 & 0.005 \\
& $(0.006)$ & $(0.007)$ & $(0.006)$ & $(0.011)$ & $(0.010)$ \\
Muslim country × & & -0.011 & -0.010 & -0.012 & -0.016 \\
After March 11, 2003 & $(0.018)$ & $(0.015)$ & $(0.015)$ & $(0.013)$ \\
& & & & & \\
Observations & 66,089 & 66,089 & 66,089 & 66,089 & 66,089 \\
R-squared & 0.010 & 0.010 & 0.186 & 0.186 & 0.196 \\
Applicant Controls & & & $\checkmark$ & $\checkmark$ & $\checkmark$ \\
Temperature & & & $\checkmark$ & $\checkmark$ & $\checkmark$ \\
Judge FE & & & $\checkmark$ & $\checkmark$ & $\checkmark$ \\
City FE & & & & $\checkmark$ & $\checkmark$ \\
Month FE & & & & $\checkmark$ & $\checkmark$ \\
City × Month FE & & & & $\checkmark$
\end{tabular}

Note: This table shows OLS estimates of Equation (1) for a placebo analysis of the March 11, 2003 attacks in Madrid. The unit of observation is a case. The dependent variable is a dummy that equals one if asylum is granted and zero otherwise. The time period is Sept. 12, 2002 to Sept. 7, 2003. Applicant controls include application type, detention status, and legal representation. Judge, city, month, and city-month fixed effects are included. Temperature is the mean temperature on the day of the hearing

from $6 \mathrm{am}-4 \mathrm{pm}$. Standard errors are clustered by country of origin and are shown in parentheses. 
Table A11: Estimation of the Effect of Sept. 11, 2001 on Any Relief Granted excluding Withdrawals and Dismissals: Six Month Window

\begin{tabular}{lccccc}
\hline & $(1)$ & $(2)$ & $(3)$ & $(4)$ & $(5)$ \\
\hline Asylee from Muslim-maj. country & 0.122 & 0.143 & 0.120 & 0.120 & 0.120 \\
& $(0.048)$ & $(0.052)$ & $(0.032)$ & $(0.032)$ & $(0.032)$ \\
After Sept. 11, 2001 & -0.024 & -0.014 & -0.005 & 0.022 & -0.005 \\
& $(0.012)$ & $(0.011)$ & $(0.009)$ & $(0.016)$ & $(0.009)$ \\
Muslim-maj. country & & -0.043 & -0.044 & -0.044 & -0.044 \\
After Sept. 11, 2001 & $(0.023)$ & $(0.017)$ & $(0.017)$ & $(0.017)$ \\
& & & & \\
Observations & 25,819 & 25,819 & 25,819 & 25,819 & 25,819 \\
R-squared & 0.011 & 0.011 & 0.236 & 0.236 & 0.236 \\
Applicant Controls & & & $\checkmark$ & $\checkmark$ & $\checkmark$ \\
Temperature & & & $\checkmark$ & $\checkmark$ & $\checkmark$ \\
Judge FE & & & $\checkmark$ & $\checkmark$ & $\checkmark$ \\
City FE & & & $\checkmark$ & $\checkmark$ \\
Month FE & & & & $\checkmark$ \\
City × Month FE & & & & $\checkmark$ \\
\hline
\end{tabular}

Note: This table shows OLS estimates of Equation (1) excluding withdrawn and dismissed cases. The unit of observation is a case. The dependent variable is a dummy that equals one if asylum is granted and zero otherwise. The time period is March 15, 2001 to March 9, 2002. Applicant controls include application type, detention status, and legal representation. Judge, city, month, and city-month fixed effects are included. Temperature is the mean temperature on the day of the hearing from $6 \mathrm{am}-4 \mathrm{pm}$. Standard errors are clustered by country of origin and are shown in parentheses.

Table A12: Varying the Threshold for Muslim-Majority Country

Full Estimation of the Effect of Sept. 11, 2001 on Any Relief Granted: Six Month Window

\begin{tabular}{|c|c|c|c|c|c|}
\hline & (1) & $(2)$ & $(3)$ & $(4)$ & $(5)$ \\
\hline Asylee from $75 \%$ Muslim-maj. country & $\begin{array}{c}0.093 \\
(0.048)\end{array}$ & $\begin{array}{c}0.110 \\
(0.048)\end{array}$ & $\begin{array}{c}0.111 \\
(0.037)\end{array}$ & $\begin{array}{c}0.111 \\
(0.037)\end{array}$ & $\begin{array}{c}0.108 \\
(0.037)\end{array}$ \\
\hline After Sept. 11, 2001 & $\begin{array}{c}-0.020 \\
(0.008)\end{array}$ & $\begin{array}{c}-0.015 \\
(0.009)\end{array}$ & $\begin{array}{c}-0.009 \\
(0.008)\end{array}$ & $\begin{array}{c}-0.006 \\
(0.011)\end{array}$ & $\begin{array}{c}-0.010 \\
(0.010)\end{array}$ \\
\hline $\begin{array}{l}75 \% \text { Muslim-maj. country } \times \\
\text { After Sept. } 11,2001\end{array}$ & & $\begin{array}{l}-0.035 \\
(0.016)\end{array}$ & $\begin{array}{l}-0.035 \\
(0.013)\end{array}$ & $\begin{array}{l}-0.035 \\
(0.013)\end{array}$ & $\begin{array}{l}-0.028 \\
(0.013)\end{array}$ \\
\hline Observations & 48,340 & 48,340 & 48,340 & 48,340 & 48,340 \\
\hline R-squared & 0.007 & 0.007 & 0.171 & 0.171 & 0.183 \\
\hline Applicant Controls & & & $\checkmark$ & $\checkmark$ & $\checkmark$ \\
\hline Temperature & & & $\checkmark$ & $\checkmark$ & $\checkmark$ \\
\hline Judge FE & & & $\checkmark$ & $\checkmark$ & $\checkmark$ \\
\hline City FE & & & $\checkmark$ & $\checkmark$ & $\checkmark$ \\
\hline Month FE & & & & $\checkmark$ & $\checkmark$ \\
\hline City $\times$ Month FE & & & & & $\checkmark$ \\
\hline
\end{tabular}

Note: This table shows OLS estimates of Equation (1). The Muslim-majority country definition is changed from $50 \%$ to $75 \%$. The unit of observation is a case. The dependent variable is a dummy that equals one if asylum is granted and zero otherwise. The time period is March 15, 2001 to March 9, 2002. Applicant controls include application type, detention status, and legal representation. Judge, city, month, and city-month fixed effects are included. Temperature is the mean temperature on the day of the hearing from $6 \mathrm{am}-4 \mathrm{pm}$. Standard errors are clustered by country of origin and are shown in parentheses. 